\title{
Perception of Message on the Display "Foto Acrylic Ini Dapatkan Diskon Seumur Hidup" to Used Batik Trusmi Groups for Customers Sambal Layah Cirebon
}

\author{
Farida Nurfalah \\ Department of Communication \\ Swadaya Gunung Jati University \\ Cirebon, Indonesia \\ faridanurfalah2@yahoo.com
}

\begin{abstract}
The management company is required to communicate and disseminate their products to the customer in order to convince customers to buy the product by spreading the advertising in various categories among which are using posters, displays installed in several public spaces. Identify the problem in this research are as follows: 1 . How to display the message "Foto Acrylic ini dapatkan diskon seumur hidup"? 2. What is the response of customer to Trusmi Batik Groups with Message on the display "Foto Acrylic ini dapatkan disk on seumur hidup "?. The method used is a qualitative descriptive study. Selection of informants by using purposive. A result that; 1 . Display the message "These Acrylic Photo to Get Discounts Lifetime" for customers Sambal Layah Cirebon, unique, easy to understand and can cause curiosity of people visit the showroom and buy the product for a discount, 2 . A response of customers to the display "for customers Sambal layah Cirebon. Trusmi Batik Groups exists in its business through batik artistic image, deepening local wisdom, discount and low price. Batik promoted in several public locations, as well as the model using the owner itself, raises intimacy in the community.
\end{abstract}

Keywords—message displays; customers

\section{INTRODUCTION}

The story of the village Batik Trusmi originated from Ki Gede Trusmi role. One of the faithful followers of Sunan Gunung Jati teaches the art of batik while spreading Islam. Batik shrewdness it turns out gave a blessing at a later date. Trusmi Batik managed to become an icon in fabric collections nationally and internationally [1].

Batik is a heritage that is rich in cultural values and fiber art that must be kept basically cannot be separated from the symbols. All the cultural meanings created by using symbols. Meaning can only be 'kept under the symbol' [2]. Knowledge of culture is more than a collection of symbols, terminology terms of the people and the types of other symbols all symbols both words are unspoken, an object such as a flag, a gesture such as waving, a place, or an event such as marriage, is a part of the symbol. medium or media exist in forms as carriers or symbolic meaning or message being communicated. A symbol is an object or any event that refers to something. Symbols include what we feel and what we experienced. Each person in a certain sense forming means to communicate symbol is a representation of empirical reality.

One vigorous in promoting trusmi batik groups that have characteristics and different from other batik company in both product and service. The world of marketing communications, is a company in services or manufacturing, it is not enough just to focus on brand image, but also must find a way or strategy to communicate a product so that people can get to know in detail from start to quality, packaging, content and the benefits of the product so that the action it will have a positive effect on the brand or product brand.

Field marketing strategy basically boils down to communication [3]. So, the management company is required to communicate and disseminate their products to the customers in order to convince customers to buy the product by spreading the ads in various categories among which are using posters, displays installed in many public spaces including at Visitor Sambal layah Cirebon city put up display "this Acrylic Photo to get Discounts Lifetime" this is very interesting and creative because it is rarely used as a marketing communication strategy. Therefore, the researchers are interested in doing the in-depth study of Perception of Customer at the Message Display "This Acrylic Photo to Get Discounts Lifetime " used Batik Trusmi Groups for Sambal layah Cirebon. "

\section{RESEARCH METHOD}

In accordance with the nature of the issues, and research to be achieved as well as the properties of the data required, in this study researchers used the method of this research is descriptive using a qualitative approach. Format qualitative description aims to describe, summarize a variety of conditions, situations, or the phenomenon of social reality in a society that becomes the object of research and aims to attract that reality to the surface as a trait, character, nature, model, sign, or a description of the condition, situation or certain phenomena [1]. Object and subject of this research study including qualitative research, which became the object of the study was the message. Researchers used the informant selection techniques with purposive sampling. Purposive sampling is a sampling technique with a data source specific 
consideration, such as the person considered most knowledgeable about what to expect, or perhaps he is the ruler that will allow researchers to explore objects and social situation investigated [2].

\section{RESUlt AND DisCUSSION}

\section{A. Display the message "This Acrylic Photo to Get Discounts Lifetime" for customers of Sambal Layah Cirebon}

1) Sensation: The use of "mega mendung" motifs on the message of batik trusmi is unique advertising, besides that it features regional characteristics because batik is a high-value artwork, as a characteristic of certain nation's culture and tradition that is Cirebon city [4,5]. Another sensation from the combination of bright colors, good and interesting appearance, even informant opinion funny and hyperbole, such as the contents of the message that prospective customers are asked to photograph the ad on acrylic found potential customers in some open areas that are often visited by the community but raises doubts on one informant because it is considered excessive that are on the ad message there is the word "lifetime discount" [6, 7, 8]. The positive thing about the advertising message that informant opinion can cause curiosity of community visit showroom and buy the product because get the discount.

2) Attention: Advertising messages can create attention if unique but make sense and benefit the community and can generate a sense of love if the product offered at that time can meet the needs $[9,10]$. Based on the advertisement, Trusmi Batik Groups is considered cheaper so that the advertisement according to the informant is right on target because it is easily understood with short and clear words, even the word "lifetime discount" can be accepted truth by an informant. Although intriguing the heart, the discount message to attract many customers, the public immediately memory acrylic photos to get a discount, so it can add customer batik trusmi group.

3) Interpretation: Ads are often someone to be curious, even from these ads make someone search for a product so eventually, buy the product $[11,12,13]$. So, the informant believes the advertising message even if it is limited to the appearance of the message. What is done by trusmi batik on acrylic containing message giving "lifetime discount" has the meaning of advertising message that is to promote and explain the product to society so interested to come to a showroom of Trusmi Batik Groups? The informant also believes that the Trusmi Batik Group can keep its promise for lifetime discounts, even hopefuls of trusmi batik groups provide other old and big discounts and advertise in various media, put display advertising in various places.

\section{B. Response of consumers to the display "This Acrylic Photo to get Discount a Lifetime" for Customers Sambal Layah Cirebon}

1) Sensation: Advertising messages should be interesting, easy to understand the language, and often advertising messages are made hyperbolic, in addition to the advertisements placed around the targeted target of the product being offered, so that the surroundings of the advertising message are known and acceptable in the environment. In the end, psychologically, advertising messages can be accepted, if it can explain a product and explain the deficiency and product advantages, in addition to advertising messages easy to understand and interesting.

Trusmi Batik Groups exists in its business by making display messages through batik artistic image, Greetings element of local wisdom, discount and cheap price. Trusmi Batik Groups can provide customers appeal to buy with the meaning of a unique advertising message, ethnic batik promoted in several public locations, and the model using the owner itself raises intimacy in the community.

2) Attention: Trusmi Batik Groups is the largest Batik Showroom in Cirebon with several showroom branches, batik style is nice and diverse, relatively cheap with the complete collection, comfortable atmosphere with friendly employees, so visitors become comfortable.

3) Interpretation: The display of unique trusmi batik advertising, characterizing the typical area can also be disseminated in various mass media and display messages can be trusted by prospective customers because to keep the good name, so customers are not disappointed, and imaging. With the use of display, messages can be proud, has a personality for the wearer and the maker so that Trusmi Batik Group can grow rapidly by highlighting cultural ethnic with accompanying advertisements on other media such as brochures, social media $[14,15,16]$.

\section{CONCLUSION}

- Display the message "These Acrylic Photo Discounts get Lifetime" for consumers visitor Sambal Layah Cirebon, unique, easy to understand and can cause curiosity of people visit the showroom and buy the product for a discount.

- The response of consumers to the display "for consumers visitor Sambal layah Cirebon. Batik Trusmi Groups exists in its business through batik artistic image, deepening local wisdom, discount and low price. Batik promoted in several public locations, as well as the model using the owner itself, raises intimacy in the community.

\section{REFERENCES}

[1] M.B. Bungin, Metode Penelitian Kualitatif. Jakarta: Kencana Prenada Media, 2006.

[2] Sugiyono, Metode Penelitian Kuntitatif Kualitatif. Bandung: Alfabeta, 2010 .

[3] E. Effendy, O. Onong and U. Uchjana, Ilmu, Teori dan Filsafat Komunikasi. Bandung: Citra Aditya Bakti, 2007

[4] J. Fiske, Pengantar Ilmu Komunikasi. Jakarta: Rajawali Pers, 2014.

[5] D. Mulyana, Ilmu Komunikasi: Suatu Pengantar. Bandung: Rosdakarya, 2010.

[6] L. Maleong, Metodologi Penelitian Kualitatif. Bandung: Remaja Rosdakarya, 2007. 
[7] J.M. Rakhmat, Metode Penelitian Komunikasi. Bandung: Remaja Rosdakarya, 2005.

[8] Wiryanto, Pengantar Ilmu Komunikasi. Jakarta: Grasindo, 2004.

[9] I. Ahmad, "Spanduk dan Stiker sebagai Media Komunikasi untuk Melaporkan Peristiwa Kependudukan," Jurnal Ilmu Komunikasi Volume 9 Nomor 1 Edition Januari-April Terakreditasi B. Departement of Communications Science Fisip UPN "Veteran" Yogyakarta and ISKI, 2011, p. 28.

[10] R.Z. Fauziah, Analisis Proses Komunikasi Pemasaran Dalam Peningkatkan Eksport Rotan di PT. Silcane Kabupaten Cirebon. Cirebon : Departement of Communications Science, 2016.

[11] A. Konaah, Strategi Komunikasi Bisnis Trusmi Grup dalam Menarik konsumen. Cirebon : Departement of Communications Science, 2016.

[12] Martika Vera, Neni Yulianita and Udung Noor Rosyad, "Strategi Komunikasi Pemasaran PT. Kereta Api Argo Parahyangan," Jurnal Signal Jilid 8 Nomor 2 Volume 4, Nomor 2, Edition Juli -Desember., 2016, p. 200.

[13] Susanti Herdiana Ayu, "Strategi Komunikasi Badan Kependudukan dan Keluarga Berencana Nasional (BKKBN)," Jurnal Komunikasi Aspikom Volume 2 Nomor 4 Edition Januari, 2015, p. 243.

[14] http://netsains.com/2008/07/keunggulan-batik-trusmi-Cirebon/ (access, September 28 ${ }^{\text {th } 2017)}$

[15] http://id.wikipedia.org/wiki/Batik(access, September $28^{\text {th } 2017)}$

[16] http://travel.detik.com/read/2015/10/02/081345/3033687/1519/wisatabatik-trusmi-cirebon-makin-lama-makin-eksis (access, September $28^{\text {th } 2017)}$ 